\title{
Analysis of influencing factors of civil aviation passenger volume in multi airport area: A case study on Yangtze River Delta
}

\author{
Zhen $\mathrm{HONG}^{*}$, and Wei WEI
}

School of Air Transportation/Flying, Shanghai University of Engineering Science, 333 Longteng road, Shanghai, 201620, China

\begin{abstract}
In order to analyse the main influencing factors of civil aviation passenger transport volume in multi Airport area. Correlation analysis, stepwise linear regression analysis and Grainger causality test were used to analyse the influence factors of civil aviation passenger traffic volume, to eliminate the invalid factors, a regression model is established to analyse the causal relationship between the various factors and air passenger volume. Through the analysis of the Yangtze River Delta region, it is concluded that the number of inbound tourists, the railway mileage and the volume of railway passenger transport are the main factors affecting the Yangtze River Delta region. Through the Grainger causality test, the air passenger volume of the Yangtze River Delta has one-way influence on the railway passenger traffic volume.
\end{abstract}

\section{Introduction}

As a modern mode of transportation, the development of air transport reflects the level of economic development of a country. With the deepening of the economic globalization and the continuous development of the civil aviation industry, The study of the development of civil aviation passenger volume and its influencing factors are not only important for air transportation, but also an important basis for the rational distribution of transport capacity in countries and regions [1]. Taking China's Yangtze River Delta region as the research object, its basic general situation is as follows table 1 :

Table 1. Basic situation of Yangtze River Delta.

\begin{tabular}{|c|c|c|}
\hline Region & City & Airport(IATA) \\
\hline $\begin{array}{c}\text { Yangtze } \\
\text { River } \\
\text { Delta }\end{array}$ & $\begin{array}{c}\text { Shanghai,Nanjing,Wuxi,Changzhou,Suzhou,N } \\
\text { antong,Yancheng,Yangzhou,Zhenjiang,Taizho } \\
\text { u,Hangzhou,Ningbo,Taizhou,Shaoxing,Huzho } \\
\text { u,Jiaxing,Jinhua,Zhoushan }\end{array}$ & $\begin{array}{c}\text { SHA } \text { PVG、NKG、WUX、 NTG、YTY、YNZ、HGH、 } \\
\text { NGB、HSN、HYN }\end{array}$ \\
\hline
\end{tabular}

While the rapid development of regional aviation industry in the Yangtze River Delta,

* Corresponding author: hzhong36@163.com 
there are many problems that can not be ignored. (1)The regional air transport industry has a serious tendency towards the distribution of air traffic and resources, and the difficulties of major hub airports and the two division [2]. As shown in figure 1.(2) Airport cooperation in the region is very low, and the airports in the region are fiercely competitive. (3) air route planning is not reasonable, homogeneous, and seriously aggregated to hub airports.

Therefore, the scientific and accurate prediction of the volume of air transport in the multi airport area has become the basis for promoting the coordination of Regional Airport groups and improving the transportation efficiency between airports. As a starting point, the scientific analysis of the Yangtze River Delta regional air transport volume factors, to identify the main influencing factors.

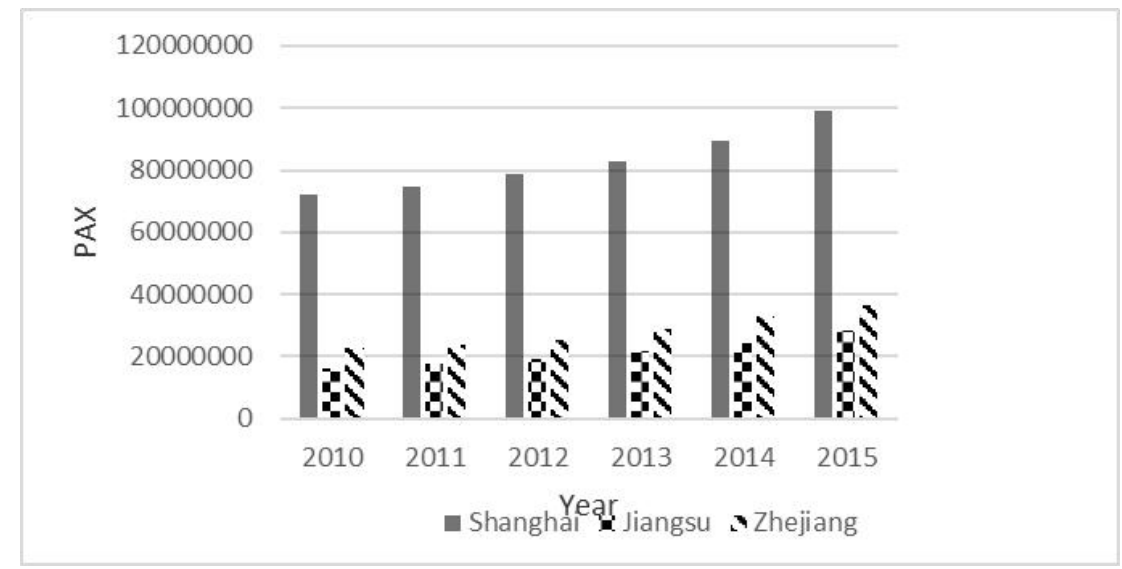

Fig. 1. Civil aviation passenger traffic volume in Yangtze River Delta.

\section{Analysis of factors affecting regional air volume in the Yangtze River Delta}

\subsection{Preliminary selection of influencing factors}

As is known to all, the aviation industry in the Yangtze River Delta has developed rapidly in recent years, and there are many factors affecting the air passenger volume, according to the selection principle of influencing factors, control variables.combined with the development of the regional civil aviation industry in the Yangtze River Delta and the regional economic characteristics and social development of the Yangtze River Delta [3]. From the four aspects of regional economic development, regional residents' living standards, regional international and domestic tourism development level and other transportation modes in the region.

\subsection{Determination of influencing factors of air passenger volume in the Yangtze River Delta region}

Through the primary election, the 10 main factors affecting the regional air transport volume of the Yangtze River Delta were identified. Are GDP, per capita GDP, per capita disposable income, the consumption level of residents, the number of domestic tourism, inbound tourism, passenger traffic volume of railway mileage, highway mileage, highway and railway passenger traffic. In order to eliminate the invalid factors and eliminate the deviation of variables, firstly, the correlation analysis of the influencing factors was 
conducted, and the correlation between the selected factors and the civil aviation passenger transportation was tested Subsequently, the stepwise linear regression method was used to analyse the factors of air transport volume in the Yangtze River Delta region, and to eliminate the ineffective factors.. Since the volume of civil aviation passenger transport in the Yangtze River Delta region is mainly concentrated in Shanghai, Hangzhou and Nanjing regions, the data of 2005-2014 years and 10 years are chosen as the research data.The variable description is as follow table 2 .

\subsubsection{Variable description}

Table 2. Variable symbol table.

\begin{tabular}{|l|l|}
\hline Variable name & Variable symbol \\
\hline Air passenger volume & $\mathrm{y}$ \\
\hline GDP & $\mathrm{x} 1$ \\
\hline Per capita GDP & $\mathrm{x} 2$ \\
\hline Per capita disposable income & $\mathrm{x} 3$ \\
\hline Resident consumption level & $\mathrm{x} 4$ \\
\hline domestic tourists & $\mathrm{x} 5$ \\
\hline Inbound tourists & $\mathrm{x} 6$ \\
\hline Railway operating mileage $(\mathrm{km})$ & $\mathrm{x} 7$ \\
\hline Highway operating mileage $(\mathrm{km})$ & $\mathrm{x} 8$ \\
\hline Railway operating mileage & $\mathrm{x} 9$ \\
\hline Highway passenger volume & $\mathrm{x} 10$ \\
\hline
\end{tabular}

\subsubsection{Correlation analysis}

Table 3. Correlation analysis of regional air passenger volume and its influencing factors in Yangtze River Delta.

\begin{tabular}{|c|c|c|c|c|c|c|c|c|c|c|c|}
\hline & $\mathrm{y}$ & $\mathrm{x} 1$ & $\mathrm{x} 2$ & $\mathrm{x} 3$ & $\mathrm{x} 4$ & $\mathrm{x} 5$ & $\mathrm{x} 6$ & $\mathrm{x} 7$ & $\mathrm{x} 8$ & $\mathrm{x} 9$ & $\mathrm{x} 10$ \\
\hline $\begin{array}{c}\mathrm{y} \text { Pearson } \\
\text { Correlation }\end{array}$ & 1 & $.320 * *$ & .196 & $.417 *$ & $.710^{* *}$ & $.940 * *$ & $.951 * *$ & $.984 * *$ & .027 & $.944 * *$ & $-.778^{* *}$ \\
\hline Sig.(2-tailed) & & .085 & .299 & .022 & .000 & .000 & .000 & .000 & .887 & .000 & .000 \\
\hline $\mathrm{N}$ & 30 & 30 & 19 & 30 & 14 & 30 & 24 & 10 & 14 & 19 & 19 \\
\hline
\end{tabular}

**: The correlation was significant at the 0.01 level (bilateral)

*: The correlation was significant at the 0.05 level (bilateral)

As can be seen the result of correlation analysis from table 3, In addition to the average per capita GDP (x2) and highway operating miles (x8) and air passenger volume (y), there is no significant correlation between the 0.05 and 0.01 confidence intervals. Significant correlations were found between 0.05 and 0.01 confidence intervals for other independent variables and dependent variables.

\subsubsection{Stepwise linear regression analysis}


Stepwise linear regression analysis was used to find out the main factors affecting the air passenger volume in the Yangtze River Delta region, elimination of invalid factors, the establishment of a regression model to explore the impact of major factors. The analysis results are shown in table 4-table 5.

Table 4. Summary of regional linear regression analysis model of Yangtze River Delta.

\begin{tabular}{|l|l|l|l|l|}
\hline Model & $\mathrm{R}$ & $\mathrm{R}$ Square & $\begin{array}{l}\text { Adjusted R } \\
\text { Square }\end{array}$ & $\begin{array}{l}\text { Std.Error of the } \\
\text { Estimate }\end{array}$ \\
\hline 1 & $.984 \mathrm{a}$ & .967 & .966 & 2382569.148 \\
\hline 2 & $.990 \mathrm{~b}$ & .981 & .980 & 1852366.181 \\
\hline 3 & $.993 \mathrm{c}$ & .987 & .985 & 18570649.970 \\
\hline Predictors: (Constant) $\mathrm{x} 7$ & \\
\hline Predictors: (Constant) $, \mathrm{x} 7, \mathrm{x} 9$ & \\
\hline Predictors: (Constant) $\mathrm{x} 7, \mathrm{x} 9, \mathrm{x} 6$ & \\
\hline
\end{tabular}

Table 5. Yangtze River Delta linear regression analysis model coefficient table.

\begin{tabular}{|l|l|l|l|l|l|l|}
\hline \multirow{2}{*}{ Model } & \multicolumn{2}{|l|}{ Unstandardized Coefficients } & $\begin{array}{l}\text { Standardized } \\
\text { Coefficients }\end{array}$ & $\mathrm{t}$ & \multirow{2}{*}{ Sig. } \\
\cline { 3 - 7 } & $\mathrm{B}$ & Std.Error & Beta & & \\
\hline 1 & Constant & -5114881.666 & 853968.619 & & -5.99 & .000 \\
\hline & $\mathrm{x} 7$ & 101992.163 & 3544.128 & .984 & 28.778 & .000 \\
\hline 2 & Constant & -6605757.266 & 745543.454 & & -8.86 & .000 \\
\hline & $\mathrm{x} 7$ & 75306.985 & 6666.716 & .726 & 11.296 & .000 \\
\hline & $\mathrm{X} 9$ & 1860.535 & 423.255 & .283 & 4.396 & .000 \\
\hline 3 & Constant & -5776983.319 & 677547.641 & & -8.526 & .000 \\
\hline & $\mathrm{x} 7$ & 59024.764 & 7409.401 & .569 & 7.966 & .000 \\
\hline & $\mathrm{x} 9$ & 1570.831 & 368.866 & .239 & 4.259 & .000 \\
\hline & $\mathrm{x} 6$ & 10143.093 & 2984.010 & .212 & 3.399 & .002 \\
\hline
\end{tabular}

As can be seen from table 4, there are 3 models in the stepwise regression analysis. Each model's regression $\mathrm{R}$ Square is more than 0.9, and the regression effect is very significant. Among them, the model's regression R Square is the largest, so model 3 is chosen as the optimal model. Secondly, table 5 shows that in model 3 , there are three independent variables, namely, inbound tourist arrivals (x6), railway miles (X7) and rail passenger traffic ( $\mathrm{x} 9$ ). The $\mathrm{P}$ values of each independent coefficient test are less than 0.05 , indicating that the independent variables in the model have a significant impact on $y$.

\subsubsection{Analysis of influencing factors of air passenger volume}

Combined with table 9, the regression model of civil aviation passenger volume and its influencing factors in the Yangtze River Delta region is as follows:

$$
Y=-5776983.319+10143.093 * x 6+59024.764 * x 7+1570.831 * x 9
$$

To sum up, the factors affecting the air passenger volume in the Yangtze River Delta 
are inbound tourism, railway operating mileage and railway passenger traffic volume, The two factors of residents' living standards are excluded, which shows that air transportation is not the preferred mode of transportation compared with railways and highways. Railway transportation and tourism have great influence on air passenger volume, which can promote the increase of air passenger volume [4].

\section{Grainger causality test}

By correlation analysis of the relationship between influencing factors and air passenger traffic, in order to study the influencing factors and the relationship between the air passenger volume, the Grainger test their causal relationship between cause and effect analysis. First, the ADF unit root test is used to determine whether the data is stationary or not; In the second step, co integration test is used to test whether all variables have co integration relationship, In the case of satisfying the two premises, the Grainger causality test is then performed, The results are shown in table 6 , table 7 , table8.

Table 6. Unit root test results.

\begin{tabular}{|l|l|l|l|}
\hline variable & T-test & P Value & Result \\
\hline Air passenger volume & -0.248742 & 0.8979 & Existence unit root \\
\hline Inbound tourist & -1.680986 & 0.4072 & Existence unit root \\
\hline Railway operating mileage & -0.541442 & 0.8382 & Existence unit root \\
\hline Railway operating mileage & 2.839897 & 0.9998 & Existence unit root \\
\hline
\end{tabular}

Table 7. First order difference unit root test results.

\begin{tabular}{|l|l|l|l|}
\hline variable & T-test & P Value & Result \\
\hline Air passenger volume & -3.44403 & 0.0425 & Inexistence unit root \\
\hline Inbound tourist & -2.763214 & 0.1053 & Existence unit root \\
\hline Railway operating mileage & -2.320209 & 0.1876 & Existence unit root \\
\hline Railway operating mileage & -1.425538 & 0.5164 & Existence unit root \\
\hline
\end{tabular}

Table 8. Two order difference unit root test results.

\begin{tabular}{|l|l|l|l|}
\hline variable & T-test & P Value & Result \\
\hline Air passenger volume & -3.082154 & 0.0809 & Inexistence unit root \\
\hline Inbound tourist & -3.903557 & 0.0276 & Inexistence unit root \\
\hline Railway operating mileage & -3.405346 & 0.0499 & Inexistence unit root \\
\hline Railway operating mileage & -4.489948 & 0.0141 & Inexistence unit root \\
\hline
\end{tabular}

Table 6, Table 7 and Table 8 indicates that the variable is assigned a two order differential equilibrium at a confidence level of 0.1 . It shows that there is a same rank stability, and Grainger causality test can be carried out. The results of the Grainger test are shown in Table 9. 
Table 9. Air passenger volume of Yangtze River Delta and its influencing factors -- Grainger causality test.

\begin{tabular}{|l|l|l|l|l|}
\hline Original hypothesis & F-statistic & Lag & P Value & $10 \%$ Level \\
\hline $\begin{array}{l}\text { The number of inbound tourists } \\
\text { (x6) is not the Grainger reason } \\
\text { for air passenger volume (y) }\end{array}$ & 4.00361 & 2 & 0.1423 & accept \\
\hline $\begin{array}{l}\text { Air passenger volume (y) is not } \\
\text { the Grainger reason for } \\
\text { inbound tourist arrivals (x6) }\end{array}$ & 0.66677 & 2 & 0.5760 & accept \\
\hline $\begin{array}{l}\text { Railway mileage (X7) is not } \\
\text { the Grainger reason for air } \\
\text { passenger volume (y) }\end{array}$ & 2.76505 & 2 & 0.2086 & accept \\
\hline $\begin{array}{l}\text { Air passenger volume (y) is not } \\
\text { the Grainger cause of railway } \\
\text { mileage (X7) }\end{array}$ & 2.09689 & 2 & 0.2693 & accept \\
\hline $\begin{array}{l}\text { Railway passenger volume (x9) } \\
\text { is not the Grainger reason for } \\
\text { air passenger volume (y) }\end{array}$ & 4.75525 & 2 & 0.1174 & accept \\
\hline $\begin{array}{l}\text { Air passenger volume (y) is not } \\
\text { the Grainger cause of railway } \\
\text { passenger volume (x9) }\end{array}$ & 8.35209 & 2 & 0.0594 & refuse \\
\hline
\end{tabular}

Through the test of Grainger causality test model, At the 0.1 confidence level, air passenger volume (y) is the Grainger cause of railway passenger volume (x9), Air passenger volume (y) has a one-way influence on railway passenger volume (x9), There is no Grainger causality between air passenger volume (y) and inbound tourist arrivals (x6) and railway operating miles (X7).

\section{Conclusion}

(1) The number of inbound tourists, railway operating mileage and railway passenger volume are the three main factors affecting the air passenger volume in the Yangtze River Delta region; That is to say [5], the tourism industry and the development of the railway transportation industry are three major aspects affecting the air passenger volume in the Yangtze River Delta region [6].

(2) Air transportation has become the first choice for inbound and outbound tourism, China's economic development continues to accelerate, the air transport industry continues to improve, Shanghai, Hangzhou and Nanjing, as major cities in the Yangtze River Delta region, are rich in tourism resources, The development of the tourism industry will stimulate the volume of air travel in the Yangtze River Delta region.

(3)With the rapid development of the high speed railway network in the Yangtze River Delta region, The dense high-speed rail network makes it easier for passengers to travel between cities. Railways, or high-speed rail transportation, are more likely to serve short haul domestic passenger transport, and aviation is the international and domestic transportation that emphasizes and long-distance, Through the organic integration of the two can promote the common development of both sides. 
(4)The volume of air passenger transport in the Yangtze River Delta is the one-way cause of the railway passenger traffic volume. On the contrary, the development of the Yangtze River Delta railway can not lead to changes in air passenger volume in the Yangtze River Delta region [7]. It shows that the airport construction in the Yangtze River Delta region is still in a stage of extensive growth, Only in accordance with national infrastructure planning and construction.

\section{References}

1. JI Y Z, DENG B, QIN X W. The Analysis of Passenger Civil Aviation and its Related Factor. Mathematics in Practice And Theory, 2012, 24:175-83.

2. ZHU W W.Analysis of Influencing Factors of Civil Aviation Passenger Volume In China Based on Partial Least Squares Regression. China Market, 2010, 41:110-12.

3. Paolo B,Antonio L. Determinants of Daily Fluctuations In Air Passenger Volumes. The Effect of Events and Holidays on Milan Malpensa Airport. Journal of Air Transport Management, 2016.

4. PENG L N.Correlation Analysis and Empirical Research on Factors Influencing Civil Aviation Passenger Volume.China Market, 2014, 35:160-61+84.

5. Bhadra D. Demand for Air Travel in the United States: Bottom-Up Econometric Estimation and Implications for Forecasts by Origin-Destination Pairs. Journal of Air Transportation, 2013, 8 .

6. Jeong H Y, Kim S C. Forcasting of International Air Transport Demand of South Region to Consider Behavior of Access.Korean Society Of Civil Engeneers, 2004, 24 : 569-578.

7. QIAN Q Y. An Empirical Study on The Factors Influencing the Development of Shanghai's Air Transport. Economic Research Guide 2010, 14:27-30. 